\title{
The Assessment of Employee Engagement Level for the Implementation of New Ways of Working
}

\author{
Fransiskus Xaverius Budiyono and John Welly
}

\section{ABSTRACT}

The employee engagement is one key success to make employee working as best as they can and it must be built to create great working condition. High level of engagement from employee can make more revenue and profit because the employees will work hard for themselves and for their company. PT ISAT employees are in transition period for the ways of working and it is the adaptation from the covid-19 pandemic and the introduction of the digital transformation.

The uncertainty of the result for new ways of working has a risk because it can make employee more engage or employee become disengage. The working type or working pattern of each employee in the new ways of working is determined by company based on the role and responsibility. There is not much employee preference influence for the assignment of the working pattern for each employee because the working pattern is determined by company. Company believe that the arrangement should be the best working arrangement to make employee be more engage to company because it accommodates business needs and the feedback from employee on the internal survey.

This study is to measure and determine the level of employee engagement in Inmarsat for the implementation of the new ways of working. The assessment of engagement level is using Peakon employee engagement model. In the survey, respondent has also been requested to answer the questions for the perception and the suggestion for the improvement. The sample used in this study is simple random sampling with the total respondents of 40 people. Distribution of the questionnaire addressed in accordance with the total number of the PT ISAT employees.

From the employee engagement survey, it is found out that the engagement level has not much different compared to the internal survey prior the implementation of the new ways of working. And from the survey result, the new ways of working contribute high level of the engagement and most employees agree and support the implementation of the new way of working. Many inputs and feedback have been received from employee to improve the implementation of the new ways of working and the proposed solutions have been provided based on the input and feedback from employee.

Keywords: business needs, employee engagement, ways of working, working pattern.

\section{INTRODUCTION}

In the past two years from early 2020 until end of 2021, almost all companies suffered due to Covid-19 pandemic. It is not only happened to the companies in specific country, but it happens to almost all countries including in Indonesia. There are many ways from government to control and manage the situation and impacted to the operation or ways of working to all companies and institutions. One of the impacts to the company or institution is forcing them to implement working from home as opposite of the normal working from office. Some company implement various version for the working from home and in some situation, government also forcing the number of the employees must be working from home or allowed to working from office. Likewise, PT ISAT Inmarsat Indonesia, called as Inmarsat, is
Submitted : January 01, 2022

Published : January 24, 2022

ISSN: $2507-1076$

DOI: $10.24018 /$ ejbmr.2022.7.1.1241

Fransiskus Xaverius Budiyono School of Business and Management, Institut Teknologi Bandung, Indonesia.

(e-mail: fransiskus_xaverius ${ }^{\circledR}$ sbm-itb.ac.id) John Welly

School of Business and Management, Institut Teknologi Bandung, Indonesia.

(e-mail: john.w@sbm-itb.ac.id)

*Corresponding Author

a subsidiary company in Indonesia whose parent company, namely Inmarsat Global Limited, also implement strict working from home for almost of the employee. Only operation critical allow to work from office such as Network Operation, Building Environment, and Security.

Due to this implementation, there is mix impact to the company. In some cases, there are many benefits such as saving on the electricity, water, spaces, transportation, etc. and in some cases, there are some disadvantages such as lack of coordination and collaboration, reduce in some creativity and innovation, and some other personal impact such as physic and mental health. Since the situation is becoming more and more complex and there is no clear indication when the pandemic will over, Inmarsat decide to release new ways of working as permanent solution and to implement new working and life balance. The working patterns for the new 
ways of working are Permanent Office Worker, Flexible/Hybrid Worker and Permanent Home Worker.

\section{LITERATURE REVIEW}

\section{A. Way of Working Framework}

Flexibility can and should work for everyone. People have busy and complex lives, both in and outside of work and it is vital to strike a balance between the two to ensure a happy and healthy workforce, and a more effective and productive organisation too. That is why people believe that flexibility, in how, when and where people do their jobs, comes built-in to the way they work. The key points of the way of working:

- Meeting business needs;

- It's all about trust;

- Measuring outcomes, not attendance;

- Personal responsibility and accountability;

- Moving More;

- Change is good;

- Working Flexibly.

Working flexibly is the norm in most organisations today, and all employees need to work in a way that balances their work commitments, the way they like to work best and their busy lives. That is why Inmarsat has created an office environment that is open, agile, and collaborative and that frees people into working in a way that is best for them. At the same time, for most people, normal place of work will be the office and regular attendance is required as it promotes good team working and collaboration.

The way for the company decides how to implement working type is vary and it depend on the needs for each company. Some companies adopt the old type of the way of working which is office centric and some companies adopt recent new ways of working especially for the company that implement the digital transformation. The flexible working or hybrid working is one of the working types that commonly used to accommodate the need from company and the employee. It needs the balance between company and employee to make sure that the working type are giving benefit for both company and employee.

Fig. 1 shows the consideration how to find the balance for the working type of assignment for each individual preference versus the business needs.

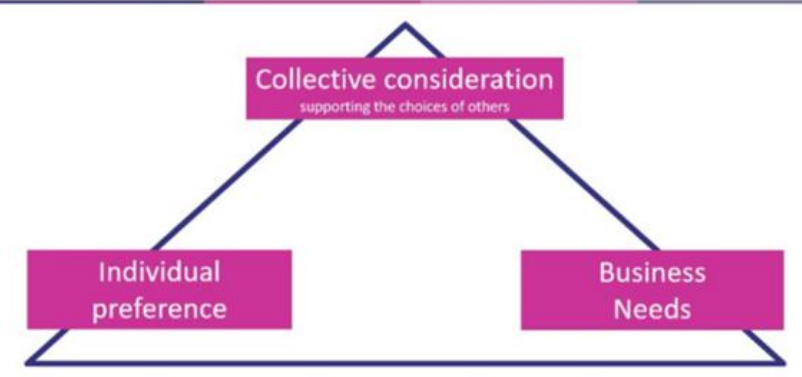

Fig. 1. Balancing for Business Needs and Individual Preference.

The working type for each individual or employee may not be same depending on the roles and responsibilities, and the business needs. Hence, the working type or working pattern for each of employee decided based on the assessment from company and company expect that employee understand and accept the decision made by company. It is expected that decision will give best result and best contribution from employee to the company.

\section{B. Peakon Employee Engagement Model}

Peakon defines employee engagement is an outcome of the relationship between an organisation and its employees. An engaged employee is fully absorbed in and enthusiastic about their work, with a high level of commitment to the company and its goals.



Fig. 2. Peakon Engagement Model.

The statement of the questionnaire is developed based on the Peakon Employee Engagement model being For the close-ended question, the rating from 1 to 5 for the total 49 statements covering all the drivers for the engagement using Peakon model and specific statement based on the implementation of the new ways of working. For open-ended questions, there are two questions, and the key point is getting the input from employee for the betterment of the new ways of working.

\section{Methodology}

The research method is conducted with quantitative research approach. Quantitative research is a means for testing objective theories by examining the relationship among variables. These variables, in turn, can be measured, typically on instruments, so that numbered data can be analyzed using statistical procedures. The purposed of this research is to provide better understanding of a research problem.

The primary data used from questionnaires. The questionnaires are combination of mainly close-ended questions and added with the open-ended questions. The questionnaire is targeted to all PT ISAT employee with minimum of participant is based on Slovin's formula to understand the engagement in relation to implementation of new ways of working in PT ISAT and it will be compared with the ways of working during the emergency covid-19 
pandemic. The secondary data come from the internal company data and from another supporting document.

In this research, the questionnaire is required to obtain the information for the employee feeling and perception for the implementation of new ways of working at Inmarsat. There are two types of the question on the questionnaire which is closed-ended question with fixed option and open-ended question to understand more and get deeper information from respondent. The question is develop based on the theoretical framework and the goal is to answer the research question. The questionnaire is sent to all PT ISAT employee using personal and company email and Google Form will used to get respond from participant. The instruction and guidance to answer the questionnaire will be given verbally and from Google Form.

Questionnaire consists of several questions, which represent the method for collecting the data for this research. The questionnaire uses Likert Scale to determine the point of each question.

The scale that will be used is from 1 to 5 , which indicated:

1. Strongly disagree;

2. Disagree;

3. Neutral;

3. Agree;

4. Strongly agree.

The questionnaires have three sections:

a) General participant data: gender, age, education, position, length of work, department, work pattern,

b) Close-ended questions for the specific statement in all aspects of the selected model.

c) Open-ended questions to get aspiration from participant.

Sampling Method

Slovin's Formula:

$$
\mathrm{n}=\mathrm{N} /\left(1+\mathrm{Ne}^{2}\right)
$$

where

$\mathrm{n}=$ Number of minimum samples;

$\mathrm{N}=$ Number of populations;

$\mathrm{e}=$ Level of sampling error

In this research the sampling error is set $10 \%$.

$$
\mathrm{n}=54 /\left(1+54 *[0.1]^{2}\right)=35.06 \sim 35
$$

Based on the calculation above, the minimum sampling size that will be used in the research is 35 respondents.

\section{DATA ANALYSIS}

\section{A. Validity and Reliability Test Result}

From the questionnaire result, the validity and reliability test are required. This is to make sure that the questionnaire result is valid and reliable. The questionnaire result is grouped based on the drivers to make it easy on the validity and reliability test. The results of validity test and reliability test

\begin{tabular}{|c|c|c|c|c|}
\hline Research Variable & Item & $\begin{array}{l}\text { Coefficient } \\
\text { Correlation } \\
\text { (rCounted) }\end{array}$ & $\begin{array}{l}\text { rTable } \\
(40: 5 \%)\end{array}$ & Result \\
\hline \multirow{3}{*}{ 1. Accomplishment } & A1 & 0.834 & 0.312 & Valid \\
\hline & $\mathrm{A} 2$ & 0.906 & 0.312 & Valid \\
\hline & B1 & 0.804 & 0.312 & Valid \\
\hline \multirow[t]{3}{*}{ 2. Autonomy } & B2 & 0.881 & 0.312 & Valid \\
\hline & B3 & 0.935 & 0.312 & Valid \\
\hline & $\mathrm{C} 1$ & 0.703 & 0.312 & Valid \\
\hline \multirow{3}{*}{ 3. Environment } & $\mathrm{C} 2$ & 0.823 & 0.312 & Valid \\
\hline & $\mathrm{C} 3$ & 0.801 & 0.312 & Valid \\
\hline & $\mathrm{C} 4$ & 0.686 & 0.312 & Valid \\
\hline \multirow{3}{*}{$\begin{array}{l}\text { 4. Freedom of } \\
\text { Opinions }\end{array}$} & D1 & 0.950 & 0.312 & Valid \\
\hline & D2 & 0.954 & 0.312 & Valid \\
\hline & D3 & 0.875 & 0.312 & Valid \\
\hline \multirow{3}{*}{ 5. Goal Setting } & E1 & 0.923 & 0.312 & Valid \\
\hline & $\mathrm{E} 2$ & 0.926 & 0.312 & Valid \\
\hline & $\mathrm{F} 1$ & 0.781 & 0.312 & Valid \\
\hline \multirow{3}{*}{ 6. Growth } & $\mathrm{F} 2$ & 0.855 & 0.312 & Valid \\
\hline & F3 & 0.852 & 0.312 & Valid \\
\hline & $\mathrm{F} 4$ & 0.697 & 0.312 & Valid \\
\hline \multirow{4}{*}{$\begin{array}{l}\text { 7. Management } \\
\text { Support }\end{array}$} & G1 & 0.881 & 0.312 & Valid \\
\hline & $\mathrm{G} 2$ & 0.943 & 0.312 & Valid \\
\hline & G3 & 0.950 & 0.312 & Valid \\
\hline & $\mathrm{H} 1$ & 0.907 & 0.312 & Valid \\
\hline \multirow{3}{*}{ 8. Meaningful Work } & $\mathrm{H} 2$ & 0.805 & 0.312 & Valid \\
\hline & H3 & 0.876 & 0.312 & Valid \\
\hline & I1 & 0.730 & 0.312 & Valid \\
\hline \multirow{4}{*}{$\begin{array}{l}\text { 9. Organizational } \\
\text { Fit }\end{array}$} & $\mathrm{I} 2$ & 0.828 & 0.312 & Valid \\
\hline & $\mathrm{I} 3$ & 0.787 & 0.312 & Valid \\
\hline & I4 & 0.802 & 0.312 & Valid \\
\hline & I5 & 0.804 & 0.312 & Valid \\
\hline \multirow{3}{*}{$\begin{array}{l}\text { 10. Peer } \\
\text { Relationships }\end{array}$} & $\mathrm{J} 1$ & 0.805 & 0.312 & Valid \\
\hline & $\mathrm{J} 2$ & 0.728 & 0.312 & Valid \\
\hline & $\mathrm{J} 3$ & 0.769 & 0.312 & Valid \\
\hline \multirow{3}{*}{ 11. Recognition } & $\mathrm{K} 1$ & 0.914 & 0.312 & Valid \\
\hline & $\mathrm{K} 2$ & 0.903 & 0.312 & Valid \\
\hline & L1 & 0.800 & 0.312 & Valid \\
\hline \multirow[t]{3}{*}{ 12. Reward } & $\mathrm{L} 2$ & 0.882 & 0.312 & Valid \\
\hline & L3 & 0.850 & 0.312 & Valid \\
\hline & M1 & 0.929 & 0.312 & Valid \\
\hline \multirow[t]{2}{*}{ 13. Strategy } & M2 & 0.929 & 0.312 & Valid \\
\hline & M3 & 0.892 & 0.312 & Valid \\
\hline \multirow[t]{2}{*}{ 14. Workload } & $\mathrm{N} 1$ & 1.000 & 0.312 & Valid \\
\hline & $\mathrm{O} 1$ & 0.789 & 0.312 & Valid \\
\hline \multirow{3}{*}{$\begin{array}{l}\text { 15. New Ways of } \\
\text { working }\end{array}$} & $\mathrm{O} 2$ & 0.869 & 0.312 & Valid \\
\hline & $\mathrm{O} 3$ & 0.909 & 0.312 & Valid \\
\hline & $\mathrm{O} 4$ & 0.759 & 0.312 & Valid \\
\hline Main Engagement & $\mathrm{Y} 1$ & 0.812 & 0.312 & Valid \\
\hline \multirow{3}{*}{$\begin{array}{l}\text { Engagement } \\
\text { Outcome }\end{array}$} & Y2 & 0.817 & 0.312 & Valid \\
\hline & Y3 & 0.868 & 0.312 & Valid \\
\hline & Y4 & 0.830 & 0.312 & Valid \\
\hline
\end{tabular}
can be seen from the Table I and Table II below.

\begin{tabular}{|c|c|c|c|c|}
\hline Research Variable & Item & $\begin{array}{c}\text { Coefficient } \\
\text { Reliability } \\
\text { Cronbach's Alpha }\end{array}$ & $\begin{array}{l}\text { Critical } \\
\text { Point }\end{array}$ & Result \\
\hline 1. Accomplishment & $\begin{array}{l}\text { A1 } \\
\text { A2 } \\
\text { B1 }\end{array}$ & 0.671 & 0.6 & Reliable \\
\hline 2. Autonomy & $\begin{array}{l}\text { B2 } \\
\text { B3 }\end{array}$ & 0.815 & 0.6 & Reliable \\
\hline 3. Environment & $\begin{array}{l}\mathrm{C} 1 \\
\mathrm{C} 2 \\
\mathrm{C} 3 \\
\mathrm{C} 4\end{array}$ & 0.747 & 0.6 & Reliable \\
\hline $\begin{array}{l}\text { 4. Freedom of } \\
\text { Opinions }\end{array}$ & $\begin{array}{l}\text { D1 } \\
\text { D2 } \\
\text { D3 }\end{array}$ & 0.916 & 0.6 & Reliable \\
\hline 5. Goal Setting & $\begin{array}{l}\text { E1 } \\
\text { E2 } \\
\text { F1 }\end{array}$ & 0.830 & 0.6 & Reliable \\
\hline 6. Growth & $\begin{array}{l}\text { F2 } \\
\text { F3 } \\
\text { F4 }\end{array}$ & 0.792 & 0.6 & Reliable \\
\hline $\begin{array}{l}\text { 7. Management } \\
\text { Support }\end{array}$ & $\begin{array}{l}\text { G1 } \\
\text { G2 } \\
\text { G3 } \\
\end{array}$ & 0.914 & 0.6 & Reliable \\
\hline
\end{tabular}

TABLE II: RELIABILITY TEST RESULT 


\begin{tabular}{|c|c|c|c|c|}
\hline 8. Meaningful Work & $\begin{array}{l}\mathrm{H} 1 \\
\mathrm{H} 2 \\
\mathrm{H} 3\end{array}$ & 0.824 & 0.6 & Reliable \\
\hline \multirow{5}{*}{ 9. Organizational Fit } & I1 & \multirow{5}{*}{0.840} & \multirow{5}{*}{0.6} & \multirow{6}{*}{ Reliable } \\
\hline & $\mathrm{I} 2$ & & & \\
\hline & $\mathrm{I} 3$ & & & \\
\hline & $\mathrm{I} 4$ & & & \\
\hline & I5 & & & \\
\hline \multirow{3}{*}{ 10. Peer Relationships } & $\mathrm{J} 1$ & \multirow{3}{*}{0.641} & \multirow{3}{*}{0.6} & \\
\hline & $\mathrm{J} 2$ & & & \multirow{2}{*}{ Reliable } \\
\hline & $\mathrm{J} 3$ & & & \\
\hline \multirow{2}{*}{ 11. Recognition } & $\mathrm{K} 1$ & \multirow{2}{*}{0.787} & \multirow{2}{*}{0.6} & \multirow{2}{*}{ Reliable } \\
\hline & $\mathrm{K} 2$ & & & \\
\hline \multirow{3}{*}{ 12. Reward } & $\begin{array}{ll}\mathrm{L} 1 \\
\mathrm{~L}\end{array}$ & \multirow{3}{*}{0.797} & \multirow{3}{*}{0.6} & \multirow{3}{*}{ Reliable } \\
\hline & L3 & & & \\
\hline & M1 & & & \\
\hline \multirow[t]{2}{*}{ 13. Strategy } & M2 & \multirow[t]{2}{*}{0.903} & \multirow[t]{2}{*}{0.6} & \multirow[t]{2}{*}{ Reliable } \\
\hline & M3 & & & \\
\hline \multirow{2}{*}{ 14. Workload } & N1 & \multirow{2}{*}{1.000} & \multirow{2}{*}{0.6} & \multirow{2}{*}{ Reliable } \\
\hline & $\mathrm{O} 1$ & & & \\
\hline \multirow{3}{*}{$\begin{array}{l}\text { 15. New Ways of } \\
\text { working }\end{array}$} & $\mathrm{O} 2$ & \multirow{3}{*}{0.835} & \multirow{3}{*}{0.6} & \multirow{3}{*}{ Reliable } \\
\hline & $\mathrm{O} 3$ & & & \\
\hline & $\mathrm{O} 4$ & & & \\
\hline \multirow[t]{2}{*}{ Main Engagement } & Y1 & \multirow{4}{*}{0.840} & & \\
\hline & Y2 & & 0.6 & Reliable \\
\hline Engagement Outcome & Y3 & & & \\
\hline & Y4 & & & \\
\hline
\end{tabular}

\section{B. Summary of Analysis}

The employee engagement can be measured from Engagement aspect in the close-ended questionnaire survey. From the Fig. 3, the score is 4.11 and it is almost same with the average score of all aspect i.e., 4.08. The New Ways of working aspect score is 4.12 and close to score for Engagement aspect and average score of all aspect. It can be concluded that the New Ways of Working aspect contribution is good enough for the overall engagement.

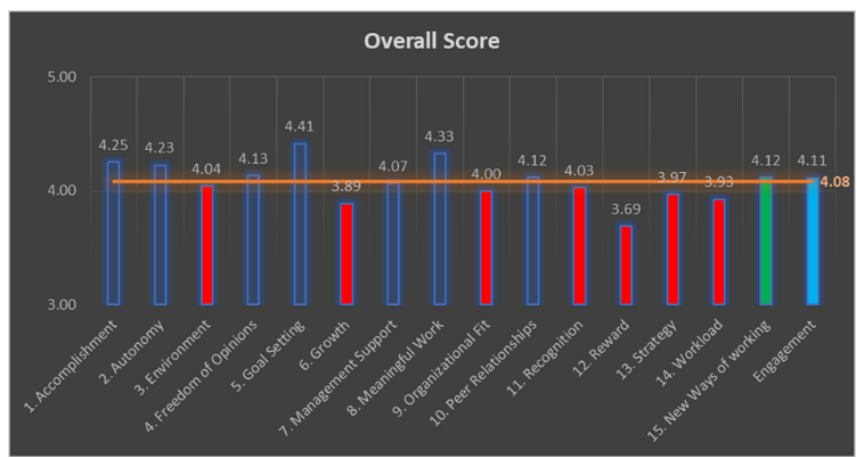

Fig. 3. Engagement and New Ways of Working Score.

For the open-ended questionnaire, from the first question, there is no objection for the implementation of the new ways of working. From all respondents, there are $82 \%$ respondent agree and fully support the implementation of the new ways of working and the working pattern, whereas $18 \%$ respondent is passive or agree with notes.

From the second question, there are some suggestions to improve the implementation such as involvement from employee for the working pattern assignment, review the working from office schedule regularly, guidance for the working in the office, flexibility for employee to decide where and when they work from office or from home, same treatment for all employee both local and global employee, the facility and incentive for supporting working from home.

\section{CONCLUSIONS}

The overall engagement level from survey in December 2021 has not much different from the survey result in January 2021 before the implementation of the new ways of working. The engagement score in December 2021 has a good level at 8.7 whereas engagement score in January 2021 is at 8.6, and it is higher than the company True Benchmark which is 7.8. Majority of the employee are engaged due to aspects of Accomplishment, Autonomy, Freedom of Opinions, Goal Setting, Meaningful Work, Peer Relationships, and New Ways of Working. It can be concluded that New Ways of Working contribute to the good level of the employee engagement. The good level of the employee engagement also strengthened by the answer from employee for the openended question, where no one has objections for the implementation the new ways of working and $82 \%$ of employee supporting the implementation.

The new ways of working need to be continued as most of the employee feel that the implementation new way of working is good for them and there is no objection for the implementation. There are some suggestions to improve the implementation such as involvement from employee for the working pattern assignment, review the schedule when employee need to work from office regularly, clear guidance for the working in the office, flexibility for employee to decide where and when they work from office or from home, same treatment for all employee both local and global employee, the facility and incentive for supporting working from home.

From the survey result it is found that the aspects causing low engagement are Environment, Growth, Management Support, Organizational Fit, Recognition, Reward, Strategy and Workload. The two lowest aspects are Growth and Reward. From the group analysis, Operation Department contribute the lowest score of the engagement compared to the other department. The lowest aspects from Operation Department are Growth, Management Support and Reward.

\section{REFERENCES}

Creswell, J. W. (2009). Research Design: Qualitative, Quantitative, and Mixed Methods Approaches. Sage Publications.

Hewitt, Aon. (2015). Trends in Global Employee Engagement. Performance, Reward \& Talent

Inmarsat Global Ltd., (2018). Inmarsat Ways of Working Framework. London, UK

Inmarsat Global Ltd., (2021). Peakon Report - Batam, January 2021. London, UK.

Inmarsat Global Ltd., (2021). Line Manager's Working Patterns Briefing. London, UK

Inmarsat Global Ltd., (2021, October). Working Patterns: Ways of Working. https://intranet.inmarsat.com/2021/04/16/working-patterns.

Kumar, R. (2011). Research Methodology: a step-by-step guide for beginners. Sage Publications.

Workday. (2021, October). The 45 Questions Your Employee Engagement Survey Needs. https://blog.workday.com/en-us/2020/02/the-45questions-your-employee-engagement-survey-needs.html.

Workday. (2021, October) A whole new way to listen to employee feedback. Available from: https://www.workday.com/en-us/products/employeevoice/overview.html. 